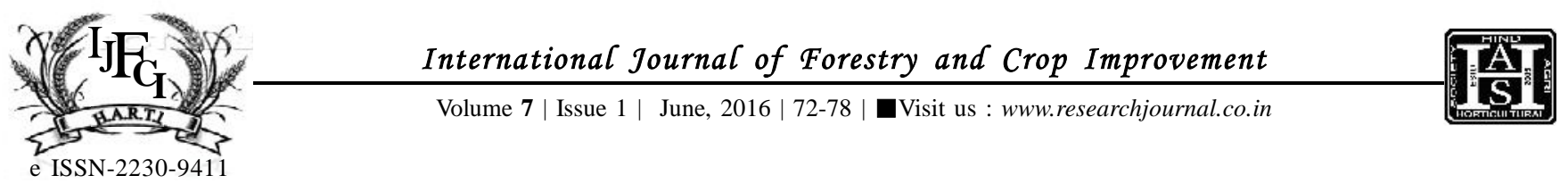

\title{
A study on marketing of cauliflower in middle Gujarat, India
}

\author{
PALAKBEn H. PATEl and R.S. PUndiR
}

\begin{abstract}
The study was carried out to estimate the price spread and marketing efficiency in the marketing of cauliflower in different channels by using different tools such as price spread, marketing costs, marketing margins and marketing efficiency. As cauliflower is a market oriented crop, on an average about 93 per cent of production was marketed, while negligible portion was utilized for other purposes. The producer to wholesaler-cum-commission agent to retailer to consumer was the major marketing channel as more that 50 per cent of cauliflower moved through this route. The total cost in marketing of cauliflower per quintal was Rs. 337.85 which was 43.19 per cent of the consumers' rupee. Amongst it the highest marketing cost was observed in retailers which accounted for as (Rs.129.25) followed by wholesaler-cum-commission agent (Rs.70.63) and growers (Rs.19.35) per quintal. Results also indicated that commission was the major marketing cost possessed by wholesaler-cum-commission agent while retailer possessed damage cost. The margins in cauliflower marketing amounted to Rs. 224.99 per quintal which was 28.76 per cent of consumers' rupee. The producer's share in consumer's rupee was 43.19 per cent. The marketing efficiency was lower than unity (0.77).Market information and provision of logistic support need to be made available to the cauliflower growers to improve existing marketing system. Further, promotion of vegetable co-operatives or vegetable producers' co-operatives can go a long way to make the existing marketing system of cauliflowers more efficient and farmers centric.
\end{abstract}

KEY WORDS : Cauliflower, Marketing costs, Margin, Marketing efficiency, Marketing channel

How TO CITE THIS ARTICLE : Patel, Palakben and Pundir, R.S. (2016). A study on marketing of cauliflower in middle Gujarat, India. Internat. J. Forestry \& Crop Improv., 7 (1) : 72-78, DOI: 10.15740/HAS/IJFCI/7.1/72-78.

ArTiCle ChronicAL : Received : 20.03.2016; Revised : 18.04.2016; Accepted : 20.05.2016

Address of the Coopted Authors : PALAKBEN H. PATEL, Gujarat Life Science Pvt. Ltd., 9-B Krishna Estate, Gorwa, VADODARA (GUJARAT) INDIA 